\title{
Orden och åldrandet
}

\section{Jan Einarsson}

På senare tid har jag, i min egenskap av smålänning med hög ålder, allt oftare funderat över ett par citat från min landsman Vilhelm Mobergs texter. (Han var född 1898 i Algutsboda församling, Kronobergs län.) Det första citatet har jag hämtat från hans skrift Otrons artiklar (1970). Där skriver han: "Vid min ålder bör en människa ha rätt att ägna sig uteslutande åt sina nöjen". Hans ålder var alltså då 72 år. Jag upprepar hans ord i mina tankar gång på gång och tillfogar uppgivet och dystert: "Om nu denna gamla människa har några av sina nöjen kvar". För Vilhelm Moberg bestod nöjet vid den här tiden i att skriva svenskarnas och smålänningarnas historia $\mathrm{i}$ boken "Min svenska historia. Berättad för folket. Från Oden till och med Dacke". Vad har då jag för nöjen att "uteslutande ägna mig åt"? Jo, jag känner mig i sällskap med den utvandrade, åldrade romanfiguren Karl Oskar, där han ligger $\mathrm{i}$ sin säng långt bort $\mathrm{i}$ Minnesota med fingret $\mathrm{i}$ kartan över hembygden. Gång på gång återupplever han den långa mil han hade att gå för att träffa sin fästmö Kristina. Båda drömmer vi oss "tillbaka till ungdomen, kärleken, tiden då vägen och livet låg framför oss" (Liljestrand 2018: 533).

För mig är ett kvarblivande och udda nöje på gamla dar att minnas och njuta av hur smålänningarna i min omgivning pratade i min ungdom. Detta tillsammans med traktens ortnamn ger mig hemkänsla och en sorts livsgemenskap in i döden. Det pratet vill jag liksom Kristina från Duvemåla i Ljuders socken ta med mig in i evigheten. För jag vill liksom hon "inte vara ensam i det eviga". Kristina vill ha sällskap av Karl Oskar: "Det var en natt när de hade haft det gott tillsammans; då sade hon till honom: "Jag vill int va ensammen i eviheten. Men jag vet att vi ska få träffas efteråt. Vi ska mötas sen. När vi inte kan dö mer.

Sverige, s. 371).

WI MÖTAS ÅTAR” (Sista brevet till

Så talade hon i sin utslitne makes minne, där han haltade fram på kyrkogården vid sjön Ki Chi Saga långt bort i Minnesota i Amerika. Där hade han själv på ett kors skurit in just dessa Kristinas tröstande ord om att de skulle åter mötas efter döden. Vid ingången till kyrkogården står de likaså trösterika orden: "Saliga äro de som här sofwa. Evig Frid är Dödens gåfwa".

Vilhelm Moberg, Karl Oskar och jag är uppvuxna i samma småländska nejd. Vi känner oss hemmastadda i samma dialekt. När Karl Oskar kände att livet närmade sig sitt slut återsåg och mindes han sin hembygd genom att titta på en karta. Genom den här texten vill jag bjuda in den skånska Gunilla 
Byrman och andra "nyinflöttade" och "nyanlända" till vår småländska språkliga gemenskap i det jordiska livet och i Kristinas evighet. Jag ska lyfta fram några drag i vårt regionala sätt att prata, drag som inte brukar uppmärksammas i andra beskrivningar, där fokus brukar ligga på bakre Rljud och diftonger. Må de jordiska orden och ortnamnen i min hembygd så småningom klinga hemtamt och välkomnande också i de nykomnas öron!

\section{"Min hembygd"}

Min hembygd sträcker ut sig längs den numera nerlagda järnvägen mellan Tingsryd och Växjö. Den centrala orten för mig är Ingelstad. Jag betraktar mig som Ingelstadpojke, trots att jag är född i Urshult, är gammal nu, och det är längesen jag bodde "hemma i Ingelstad".

Under alla de år som jag har varit hemifrån har jag då och då för mig själv - som i en sorts terapi och poesi - mumlat namnen på stationerna och hållplatserna norrut och in till stan: Krokvik (som senare fick byta namn till Torsjövik), Tegnaby, Bramstorp, Skir och Växjö. Det var via de orterna som tåget tog mig "te stan", till Växjö högre allmänna läroverk, till Kungl. Kronobergs regemente (där Vilhelm Moberg gjort tjänst som "malaj”), och så småningom för min egen del till Lunds universitet och Linnéuniversitetet. Åt söder gick tåget från Ingelstad mot mina förfäders hemtrakter förbi Brände kvarn, Skye och Uråsa till Snappahem och Lidhem, där min farfar var möllare och statare på baron Leijonhufvuds gods. Mitt emellan Väckelsång och Kvarnamåla hade min mormor ett hemman, i Snärshult.

Blekinge längre söderut, där "sillastryparna" bor, ingår förstås inte i min hembygd. Landskapsgränsen mellan Småland och Blekinge utgör min hembygds sydliga gräns. Den nordliga gränsen går norr om Växjö. Att jag drar gränsen där har flera kulturgeografiska skäl. Alla bussar och tåg hade t.ex. sin slutstation där. Det var centralorten. Hur skulle man kunna ta sig från Ingelstad till exempelvis Moheda? Eller vad orterna kunde heta där långt bort på "annra sian stan". Det var en fråga som vi ungdomar aldrig behövde ställa oss. Vi höll till på "denna sian stan". Där spelade vi fotboll mot varandra, där dansade vi på lördagskvällarna med ungdomarna från de närmast liggande byarna, i Björkparken i Linneryd och i Lövhyddan i Värends Nöbbele. Pojkarna deltog i dansbaneslagmål. De slogs inte om flickor, brännvin eller något annat påtagligt åtråvärt, utan slagsmålen var en sorts skådespel med rituell karaktär och med andäktiga åskådare.

Det kunde börja så här: Ingelstadbo säger till Väckelsångsbo: "Kalla mej bonn-jävel!", och den tilltalade svarade enligt de oskrivna reglerna: "Bonnjävel!". Sedan var det bara till att slåss lite lagom allvarligt, så mycket så att det blev något att prata om under den kommande arbetsveckan.

Min fridsamme far brukade på söndagsmorgnarna inte fråga mig om jag hade haft trevligt och dansat med någon snygg flicka på lördagskvällen. Nej, hans nyfikna fråga var: "Slogs dom?" 
Om jag någon gång dristade mig till att föreslå för kamraterna att vi skulle åka till dans någonstans utanför det vanliga området, t.ex. till Folkparken eller Folkets hus i Växjö, så fick jag av kamraterna lära mig att detta var ett idiotiskt och ogenomförbart projekt. Ja, rentav högfärdigt! Det visade bara hur fördärvligt det var att "gå i stan", dvs. gå på Läroverket och göra sig märkvärdig.

\section{Konga härad i Värend i Världen}

När jag nu försöker ringa in vad som är min hembygd, finner jag att det är Konga härad. Det ligger i Värend som är ett av de "små land" som bildade landskapet Småland. De gränser som vi höll oss inom när vi roade oss på dansbanor och fotbollsplaner var de gamla häradsgränserna.

På Kungl. Kronobergs regemente (I11) låg jag på en "lucka", ett logemente, där det fanns en gammal vapensköld med texten "Konga kompani”. Det var på det kompaniet som också Vilhelm Mobergs soldat Rask hade tjänat som knekt till rotens, häradets, hembygdens och rikets värn.

I Blendasägnen från slutet av 1600-talet berättas det om den smarta och kraftfulla Värendskvinnan Blenda. Hon tog befälet över sina medsystrar och besegrade en dansk fiendehär som trängde in i Värend, medan traktens män (virdarna) var på krigståg i Västergötland. Blenda och de andra Värendskvinnorna bjöd då in de fientliga danskarna till ett gästabud på Bråvalla hed. När så danskarna var rikligt trakterade och ordentligt berusade blev de stuckna till döds av Blenda och hennes medsystrar. Som belöning för detta lär kvinnorna i Värend ha fått samma arvsrätt som männen. - Ett steg mot jämställdhet.

Häradet var en rättslig enhet. Medborgare inom häradet som begick brott fick sin dom vid häradsrätten, och Konga härads tingsplats låg fram till 1900-talets början i Ingelstad. Indelningen i härader härstammar från 900talet. Tusen år senare, vid mitten av 1900-talet, rörde vi oss alltså fortfarande huvudsakligen mellan häradets socknar, när vi skulle utöva så centrala, kulturella aktiviteter som att dansa, slåss och spela fotboll. Socknarna i häradet var: Hovmantorp, Furuby, Hemmesjö, Tegnaby, Växjö landsförsamling, Värends Nöbbele, Ö. Torsås, Långasjö, Älmeboda, Tingsås, Uråsa. (Tack vare Vilhelm Moberg är nog Ljuder Sveriges till namnet mest kända kommun och Konga det mest kända häradet.) I tusen år har folket i den här bygden varit förenat. Det har varit nödvändigt att byta buss eller tåg om man ville ta sig ut till andra delar av världen. Och jag känner inte till någon person i min släkt före min egen generation som har bosatt sig utanför häradet - såvida de inte har utvandrat till Amerika.

Det är väl inte konstigt att jag vill kalla detta för "min hembygd"! Det är där folk pratar en dialekt som ger mig hemkänsla och skänker samhörighet med mitt ursprung, med mina förfäder och förmödrar - med Karl Oskar och Kristina. 


\section{Så pratade vi därhemma}

De allra flesta av världens cirka 7000 olika språk har ett rullande tungspets$r$. Därhemma i Konga härad betraktar vi det nog som en smula fisförnämt att prrrata fint på det sättet.(di gör saj markvardia.) Det är så småflickor pratar i sina roll-lekar när de leker "fina damer". Det bakre, skorrande R-et finns i franskan, och det betraktas där som tecken på förnämhet. Det ursprungliga, rullande $r$-et finns i de andra romanska språken, t. ex. i italienskan, spanskan och i lantliga delar av Frankrike. Det låter "bonnigt" i franska öron, och på teatrarna får därför lantliga rollfigurer ofta prata med tungspets- $r$. I Sverige får motsvarande rollgestalter prata "teatersmåländska" med skorrande, bakre $R$ och diftonger.

En del personer från det sydsvenska R-området lägger sig till med rullande tungspets- $r$ samtidigt som de inte kan lägga av med de sydliga diftongerna och får problem med supradentalerna. De får på så sätt en blanddialekt. Många uppfattar en sådan blandning som tecken på att talaren gör sig märkvärdig och inte går att lita på.

Personer som talar renodlade småländska dialekter förknippas däremot med pålitlighet, ärlighet, strävsamhet och sparsamhet, ja ibland t.o.m. med snålhet. De är helt enkelt "redia". De kan t.ex. analysera ett ekonomiskt läge och dra slutsatsen: "De gaur te lite pängar saunt", d.v.s. 'det går till lite pengar sådant'. De kan ge raka råd i kniviga situationer: "Nu ska vi inte krabba te at sa hiskelit, de e ingen nöttan me de", d.v.s. 'nu ska vi inte krångla till det så förfärligt, det tjänar ingenting till'.

\section{Budskapen vi gav}

Jag ska inte gå närmare in på de uttalsdrag som skiljer småländska dialekter från den dialektlösa, neutrala språkliga variant som vi kallar rikssvenska eller standardsvenska, den som ligger nära det skrivna språket och som egentligen inte har geografisk, stark förankring någonstans. En person som talar standardsvenska avslöjar inte var hen har sin hembygd, så som dialekttalare gör. Jag ska istället beskriva två drag som inte brukar behandlas $\mathrm{i}$ olika beskrivningar av dialekter. Det är två hembygdsförankrade drag som jag är särskilt fäst vid.

Först den eftertänksamma och beslutsamma betoningen, t. ex. "Vi ska nock klara opp'at, så vi ska." Jag hörde för en tid sedan i radion hur en yngling från Lantbruksgymnasiet i Ingelstad berättade om sin relation till jordbruksmaskiner. Han tog till starka ord för att uttrycka sina känslor, ovanligt starka för en pojke $\mathrm{i}$ hans ålder och från den här trakten. Han sa: "Jag älskar traktorer, så jag gör". Sådana eftertänksamma, upprepande förstärkningar av det redan sagda kan också ta sig andra former, så de kan. Men gemensamt för dem är att de brukar uttalas långsamt, liksom för att fylla ett tomrum i väntan på att det tidigare sagda ska sjunka in och ta plats $i$ samtalspartnerns sinne. 
Med det andra exemplet vill jag illustrera hur dialektens uttrycksfullhet kan nå bortom det vanliga talade och skrivna språkets uttrycksförmåga på ett annat och förunderligt sätt. (Och nu skulle jag egentligen behöva ha en älskads ansikte i mina händer, när jag kärleksfullt ska tala om för henne hur go' hon är - inte bara god. Men jag făr försöka en älskad goding förutan och ber om läsarens inlevelse.) Jag håller hennes ansikte i mina händer, skakar dem lite lätt, ser in i hennes ögon, vrider mitt eget huvud från sida till sida och börjar tala ömsint $\mathrm{i}$ ett långsamt tempo som ökar något efter hand. Jag säger: "Du e sssa goa, sssa goa sss'at+inandning+smackning+liten hostning".

Det här är ett allmänt förstärkande uttryck som kan användas också vid nedsättande utsagor:

"Du e sssa dumma, sssa dumma sss'att+inandning+smackning+liten hostning". För att uppnå ännu större tydlighet kan man vid alla tillfällen lägga till: "De e s'att en vell illhooja", dvs. 'Det är så att man vill gallskrika'.

Uttrycket kan också användas t.ex. vid samhällskritiska analyser som i exemplet:

"De e sa passens rottet sss'att+inandning+smackning+liten hostning", dvs. 'detta är så pass ruttet, så att det finns inga ord för det'.

Vårt småländska uttryckssätt går alltså utanför de vanliga ordens betydelsegränser. Det får en ordlös uttrycksfullhet som andra språk inte mäktar med. "Di tyar liksom inte me at".

$$
* * *
$$

Så är det, så det är så.

\section{Litteratur}

Liljestrand, Jens (2018), Mannen i skogen. En biografi över Vilhelm Moberg. Stockholm: Albert Bonniers Förlag.

Moberg, Vilhelm (1970), Min svenska historia. Berättad för folket. Från Oden till och med Dacke. Stockholm: Norstedts Förlag AB.

Moberg, Vilhelm (1973), Otrons artiklar. Läsning i blandade ämnen. Göteborg: Författarförlaget.

Moberg, Vilhelm (1959 [första utgåva]), Sista brevet till Sverige. Albert Bonniers Klassiker. 